\title{
The Influence of Farmers Characteristics on Income Improvement of Laying Hens in Bangli District, Bali Province
}

\author{
I Gusti Agus Maha Putra Sanjaya ${ }^{1^{*}}$, I Dewa Nyoman Sudita ${ }^{2}$, Ketut Irianto ${ }^{3}$, Ni Made \\ Yudiastari $^{4}$ \\ Universitas Warmadewa, Denpasar, Bali-Indonesia
}

\{iga.sanjaya@gmail.com ${ }^{1}$ \}

\begin{abstract}
This study aims to determine the effect of individual farmers characteristics (age, formal education, knowledge, number of livestock ownership, and length as farmers) on the income level of laying hens farmers, and to determine which indicators of individual farmers characteristics variables have the most dominant influence on the income level of laying hens. The research was conducted in Bangli Regency, Bali Province. Research location is determined using purposive sampling method. The number of samples used as respondents in this study amounted to 40 farmers. Primary data collection was carried out using the direct interview method to farmers using a structured questionnaire. Data were analyzed using Partial Least Square (PLS). The results of the direct effect test prove that the individual farmers characteristics have a positive and significant impact on the farmers income level, where knowledge (X3) is the most dominant indicator of influencing this variable.
\end{abstract}

Keywords: Laying Chickens; Individual Characteristics; Farmers Income

\section{Introduction}

The increasing level of education, awareness of the importance of animal protein for health, lifestyle, and increasing per capita income of the community has encouraged the development of the livestock industry in Indonesia. The poultry industry can be said to be the fastest growing industry compared to the ruminant livestock industry, large and small, as well as the pig farming industry. This rapid development has certainly had a positive impact on the widening of business opportunities in this sector. The market opportunities for products produced by the poultry industry in Indonesia are currently quite promising. From a marketing perspective, the poultry industry products do not experience any significant problems. This is because the community's need for poultry products, especially eggs, is quite large. It is proven that animal food products sourced from purebred chickens have contributed around $55 \%$ of the national demand for meat and $71 \%$ for eggs, the rest is fulfilled by free-range chicken, duck, and quail eggs. [1] states that from a marketing perspective, the production capacity of layer chicken farms has not yet reached the actual production capacity in Indonesia. Characteristically, laying hen products are elastic to changes in the per capita income of the community. The higher the level of income per capita, education, and public awareness of the value of nutrition and health, the higher the demand for eggs in the market. 
Laying hens are genetically superior in terms of producing more eggs than other types of chickens during the rearing phase. [2] states that laying hens are adult hens that are raised specifically to take their eggs. On the other hand, [3] said that laying hens are chickens that are specially selected and raised to produce eggs. Genetic selection carried out on this type of chicken aims to produce laying hens that are productive and have high economic value in maintenance. The advantages possessed by laying hens include having a shorter growth rate and time to reach sexual maturity, higher productivity in producing eggs, having the ability to convert feed into better eggs, and having a longer laying period [4].

The egg consumption level of Indonesian society shows a graph that continues to increase every year. The national average consumption of eggs of broilers is 18.16 kilograms per capita per year. Meanwhile, [5] noted that the national demand for eggs from broilers until May-June 2019 reached 326,329 tons. Meanwhile, the Balinese consume an average of 8.85 items/capita/month or 106.2 items/capita/year. This data shows that the opportunity to develop a layer of laying chicken farm in Bali is still promising. To achieve business success, apart from being influenced by external factors, the success of a farmer in running his farm business is also greatly influenced by factors from within the farmer. Factors from within the farmer are also called individual characteristics. Individual characteristics are the overall abilities and behaviors inherent in the individual as a result of environmental influences [6]. Furthermore, it is said that individual characteristics can be measured through attitudes, interests, needs, age, gender, years of service, education level, and marital status.

[7] reported that farmers characteristics are proven to have a positive and significant effect on the processing of cattle waste in the Simantri group in Bali. Simantri skill is the strongest indicator to reflect the variable of farmers characteristics because it has the highest weight measurement value. The results of research from [8] show that the variables of the lactation livestock population, age of the respondent, education, farmer experience, the amount of animal feed and the amount of additional feed have a significant effect on the income variable On the other hand, [9] revealed that education and land tenure had a very significant positive relationship with access to agricultural information, while age and farming experience had an insignificant relationship. This study aims to determine the effect of individual farmer characteristics (age, formal education, knowledge, number of livestock ownership, and length of breeding) on the income level of laying breed chicken breeders, as well as to find out what indicators of individual farmer characteristics variables have the most dominant influence on farmer income levels. laying breed chicken in Bangli Regency, Bali Province.

\section{Material and Methods}

The research was conducted in Bangli Regency, Bali Province. The selection of the research location was determined using the purposive sampling method, which is a method of determining the research area based on certain considerations [10]. The population studied in this research were laying hens farmers in Bangli Regency, Bali Province. Meanwhile, the target population is farmers who have been in the business of laying hens for at least two years and raising at least 1000 layer chickens. Samples to be used as respondents in this research were taken from the target population group. The method used in sampling is simple random sampling. The total number of samples taken was 40 farmers.

The data collected in this study consisted of two types, namely primary data and secondary data. Primary data collection was carried out using the interview method which was directly 
carried out to laying hen farmers by using a structured list of questions that had been prepared in advance with the contents following the research objectives. The variables in this study consisted of independent variables and dependent variables. Individual farmers characteristics (X) are independent variables consisting of five indicators, including age $\left(\mathrm{X}_{1}\right)$, formal education $\left(\mathrm{X}_{2}\right)$, knowledge $\left(\mathrm{X}_{3}\right)$, number of livestock ownership $\left(\mathrm{X}_{4}\right)$, length of time as farmers $\left(\mathrm{X}_{5}\right)$. Meanwhile, the income level of layer hens farmers $(\mathrm{Y})$ is the dependent variable.

To analyze the effect of individual farmer characteristics variables on the income level of laying hens and to analyze what indicators of individual farmer characteristics variables that most dominantly affect the income level of laying hens farmers in Bangli Regency, Bali Province, structural equation modeling (SEM) analysis is used. based on variance or component-based SEM, known as Partial Least Square (PLS) [11].

\section{Results and Discussion}

\subsection{Individual Farmers Characteristics}

a. Age

Age is a time that can measure the existence of an object or living thing. For a farmers, age can affect his physical ability or productivity at work, way of thinking, and the ability to accept innovations in managing his business. The distribution of respondents based on age in this study can be seen in Table 1 below.

Table 1. Distribution of Respondents by Age

\begin{tabular}{cccc}
\hline No & Age Range & $\begin{array}{c}\text { Number of } \\
\text { Respondents }\end{array}$ & $\begin{array}{c}\text { Percentage of } \\
\text { Respondents (\%) }\end{array}$ \\
\hline 1 & $0-15$ Year & 0 & 0 \\
2 & $16-30$ Year & 7 & 17,5 \\
3 & $31-45$ Year & 23 & 57,5 \\
4 & $46-60$ Year & 8 & 20,0 \\
5 & $61-75$ Year & 2 & 5,0 \\
\hline & Total & 40 & 100 \\
\hline
\end{tabular}

Based on the results of data analysis, $57.5 \%$ of respondents were in the age range of 31 45 years. The youngest respondents were 24 years old and the oldest was 65 years old. It can be seen here that most of the respondents $(95 \%)$ are in the productive age range. This is following the Manpower Act No. 13 of 2003 which states that labor is anyone who can work to produce goods and services both for fulfilling their own needs and for the wider community. The working-age limit that applies in Indonesia is in the age range of 15-64 years. In general, an individual who is in a productive period will have a high level of creativity, work motivation, and work morale. This result is in line with [12] which states that together age, education, and wages have a positive and significant effect on labor productivity. [13] states that the older a person is, the less dependent he is on others or it can be said that the more independent the individual is. Furthermore, the younger the farmers (productive age 2045 years), the higher their curiosity towards an object will be as well as their interest in adopting the introduction of technology will be higher as well.

a. Formal Education

Formal education can be defined as a type of education that is tiered and structured in schools with certain requirements that have been regulated and set by the government. Formal 
education is one important aspect that must be fulfilled to improve the quality of human resources. The higher the level of formal education a person has will usually be accompanied by an increase in knowledge, reasoning power, analysis, and abilities. Based on the research results, the formal education of the respondents can be seen in Table 2 below.

Table 2. Distribution of Respondents Based on Formal Education

\begin{tabular}{cccc}
\hline No & $\begin{array}{c}\text { Formal Education } \\
\text { Level }\end{array}$ & $\begin{array}{c}\text { Number of } \\
\text { Respondents }\end{array}$ & $\begin{array}{c}\text { Percentage of } \\
\text { Respondents (\%) }\end{array}$ \\
\hline 1 & Elementary School & 5 & 12,5 \\
2 & Junior High School & 3 & 7,5 \\
3 & Senior High School & 18 & 45,0 \\
4 & Diploma Degree & 9 & 22,5 \\
5 & Bachelor Degree & 5 & 12,5 \\
\hline & Total & 40 & 100 \\
\hline
\end{tabular}

In Table 2, it can be seen that the majority (80\%) of laying hens farmers in Bangli Regency have an education starting from high school to bachelor degree (S1). Meanwhile, only $12.5 \%$ have elementary education and $7.5 \%$ have a junior high school education. This indicates that the laying hen's farmers already have a high awareness of the importance of education for their future. There is a current trend where young farmers are more concerned with formal education. This is reflected in the increasing number of respondents who graduated from high school, diploma, and bachelor's degrees. This phenomenon is different from the concept of breeders in the past, where they were not so concerned with their level of formal education. The level of education greatly determines a person's ability to make decisions, so that they can create something [14].

b. Knowledge

Sufficient knowledge of farmers regarding the management of a layer chicken farm is one of the capital that must be owned by a farmers in addition to capital in the form of land and finance. Good knowledge and understanding of the laying hen farm business will enable farmers to be able to find solutions to every problem he faces for the sake of the progress of his business. Based on the research results, the level of knowledge of the respondents can be seen in Table 3 below.

Table 3. Distribution of Respondents Based on Knowledge

\begin{tabular}{cccc}
\hline No & $\begin{array}{c}\text { Knowledge } \\
\text { Level }\end{array}$ & $\begin{array}{c}\text { Number of } \\
\text { Respondents }\end{array}$ & $\begin{array}{c}\text { Percentage of } \\
\text { Respondents (\%) }\end{array}$ \\
\hline 1 & Very High & 13 & 32,5 \\
2 & High & 21 & 52,5 \\
3 & Moderate & 6 & 15,0 \\
4 & Low & 0 & 0 \\
5 & Very Low & 0 & 0 \\
\hline & Total & 40 & 100 \\
\hline
\end{tabular}

The results showed that the level of knowledge of most farmers $(52.5 \%)$ on the management of laying hens was in the high category. Only 6 farmers $(15 \%)$ had a moderate level of knowledge and the remaining $32.5 \%$ of farmers had a very high level of knowledge on the management of laying hens. The high knowledge of these farmers cannot be separated 
from the desire of these young farmers to open themselves to all industrial developments and management of layer chicken farms. Knowledge about the management or governance of laying hens is obtained through direct experience and the experience of others. [15] said that knowledge starts with someone's curiosity to know an object, understand it apply it to real life, and perform analysis, synthesis, and evaluation of that object.

\subsection{Number Of Livestock Ownership}

The number of livestock ownership shows how much livestock a farmers can raise. The ability of farmers to raise their livestock is quite diverse. Many factors affect the ability of these farmers to raise their livestock. In general, the more livestock that can be maintained properly and produce optimally, the greater the level of profit enjoyed by the farmers. Based on the research results, the number of livestock ownership of the respondents can be seen in Table 4 below.

Table 4. Distribution of Respondents Based on Number of Livestock Ownership

\begin{tabular}{cccc}
\hline No & $\begin{array}{c}\text { Range of } \\
\text { Livestock Ownership }\end{array}$ & $\begin{array}{c}\text { Number of } \\
\text { Respondents }\end{array}$ & $\begin{array}{c}\text { Percentage of } \\
\text { Respondents (\%) }\end{array}$ \\
\hline 1 & $0-1.000$ birds & 0 & 0 \\
2 & $>1.000-5.000$ birds & 8 & 20,0 \\
3 & $>5.000-10.000$ birds & 20 & 50,0 \\
4 & $>10.000-15.000$ birds & 8 & 20,0 \\
5 & $>15.000$ birds & 4 & 10,0 \\
\hline & Total & 40 & 100 \\
\hline
\end{tabular}

The results showed that most respondents $(50.0 \%)$ raised laying hens in the range $>5,000-10,000$ birds. This number shows that most of the farmers are smallholders. This is following Government Regulation No. 25 of 2000 which states that the criteria for smallholder farmers are those who raise laying hens with a number below 10,000. The large number of layer chicken farmers who are classified as smallholder farmers in Bangli Regency is more due to collisions with capital problems. Capital is a business factor that must be provided before a person or business entity will conduct its business activities. [16] states that the size of the amount of available capital in the form of money and goods will affect business development and income achievement.

\subsection{Length Time As Farmers}

The length of farmers is the length of time for farmers to raise livestock for commercial purposes. The length of time of farmers from someone will indirectly affect his experience to raise livestock. Based on the research results, the length of time as farmers of the respondents can be seen in Table 5 below.

Table 5. Distribution of Respondents Based on Length Time As Farmers

\begin{tabular}{cccc}
\hline No & $\begin{array}{c}\text { Range of } \\
\text { Length Time As Farmers }\end{array}$ & $\begin{array}{c}\text { Number of } \\
\text { Respondents }\end{array}$ & $\begin{array}{c}\text { Percentage of } \\
\text { Respondents (\%) }\end{array}$ \\
\hline 1 & $0-1$ Year & 0 & 0 \\
2 & $>1-5$ Year & 6 & 15,0 \\
3 & $>5-10$ Year & 19 & 47,5 \\
4 & $>10-15$ Year & 10 & 25,0 \\
5 & $>15$ Year & 5 & 12,5 \\
\hline
\end{tabular}




\begin{tabular}{ccc}
\hline Total & 40 & 100 \\
\hline
\end{tabular}

The results showed that most of the respondents $(47.5 \%)$ had time to raise livestock that was in the range of $>5-10$ years. The facts in the field show that indeed most of these layer chicken farmers are dominated by new farmers with a young age and farmers who are the second generation of laying chicken farmers who are there. However, that does not mean they are less successful in adopting technology and managing their business. [17] revealed that the long experience a farmers has in running his livestock business, the more knowledge will be obtained. Furthermore, the more knowledge the farmers will have the right mindset in making decisions for the progress of the management of their livestock business.

\subsection{Farmers Income Level}

From the research results, it was found that most farmers $(40.0 \%)$ earned income from their laying hens' business per month around $>25,000,000-50,000,000$. Furthermore, as many as 13 people $(32.5 \%)$ earned an income ranging from $>50,000,000-75,000,000,3$ people $(7.5 \%)$ earned about $>75,000,000-100,000,000$. Each of the 4 breeders $(10 \%)$ earned the highest income with a range of $>100,000,000$ and the lowest income ranging from 0 $25,000,000$. The varying levels of income of layer farmers in Bangli Regency, Bali Province are caused by the number of livestock raised, the efficiency of production costs, and the selling price of eggs. [18] stated that the selling price is closely related to income because the selling price of the product which is determined will provide income or profit to the producer.

\subsection{Validity and Reliability Test}

Based on the recapitulation of research instrument validity test results, it can be seen that all the calculated R-values are greater than the r-table namely 0.30 . Therefore, all items in each research variable are declared valid. It means that age $\left(\mathrm{X}_{1}\right)$, formal education $\left(\mathrm{X}_{2}\right)$, knowledge $\left(\mathrm{X}_{3}\right)$, number of livestock ownership $\left(\mathrm{X}_{4}\right)$, length of time as farmers $\left(\mathrm{X}_{5}\right)$ are valid indicators to reflect the individual farmers characteristics $(X)$. Where knowledge $\left(X_{3}\right)$ is the most dominant indicator influencing this variable. For more details, the results of the validity and reliability tests can be seen in tables 6 and 7 below.

Table 6. Recapitulation of Research Instrument Validity Test Results

\begin{tabular}{clccc}
\hline Variable & \multicolumn{1}{c}{ Indicator } & r-value & r-table & Explanation \\
\hline & Age $\left(\mathrm{X}_{1}\right)$ & 0,889 & 0,30 & Valid \\
Individual & Formal Education $\left(\mathrm{X}_{2}\right)$ & 0,869 & 0,30 & Valid \\
Farmers & Knowledge $\left(\mathrm{X}_{3}\right)$ & 0,920 & 0,30 & Valid \\
Characteristics & Number of Livestock Owmnwership $\left(\mathrm{X}_{4}\right)$ & 0,873 & 0,30 & Valid \\
$(\mathrm{X})$ & Length Time As Farmers $\left(\mathrm{X}_{5}\right)$ & 0,845 & 0,30 & Valid \\
\hline
\end{tabular}

Table 7. Recapitulation of Research Instrument Reliability Test Results

\begin{tabular}{ccc}
\hline Variable & Cronbach's Alpha & Explanation \\
\hline Individual Farmers Characteristics (X) & 0,918 & Reliable \\
\hline
\end{tabular}

\subsection{Evaluation Results of the Measurement Model (Outler Model)}

The evaluation of the outer model is also called the evaluation of the measurement model which use to assess the validity and reliability of the model. The more complete results of the evaluation of the measurement model (outer model) can be seen in Figure 1. 


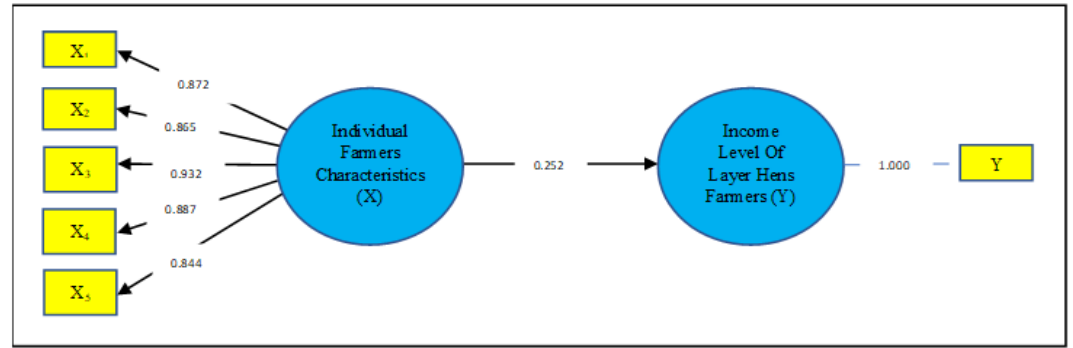

Figure. 1. Outer Model

\subsection{The Effect of Individual Farmer Characteristics (X) on Farmers Income Level (Y)}

The $p$-value of the individual farmers characteristics variable on to the income level of layer hens farmers is 0.034 which is compared with a significant value of 0.05 . The p-value < significant $(0.034<0.05)$ with a positive beta value of 0.252 and a t-statistic value of 2.128 compared to the t-table of 1.96 . Since the t-statistic value $>t$-value $(2.128>1.96)$, it can be concluded that the individual farmers characteristics have a significant and positive effect on the income level of layer hens farmers. More details can be seen in Table 8 below.

Table 8. Direct Effect Test Results

\begin{tabular}{|c|c|c|c|c|c|}
\hline & $\begin{array}{c}\text { Original } \\
\text { Sample (O) }\end{array}$ & $\begin{array}{l}\text { Sample } \\
\text { Mean } \\
\text { (M) }\end{array}$ & $\begin{array}{l}\text { Standard } \\
\text { Deviation } \\
\text { (STDEV) }\end{array}$ & $\begin{array}{c}\text { T Statistics } \\
(|\mathrm{O} / \mathrm{STDEV}|)\end{array}$ & $\begin{array}{c}\mathbf{P} \\
\text { Values }\end{array}$ \\
\hline Individual $\quad$ Farmers & & & & & \\
\hline $\begin{array}{l}\text { Characteristics }(X) \\
\text { >Income Level Of } \\
\text { Hens Farmers (Y) }\end{array}$ & 0,252 & 0,245 & 0,119 & 2,128 & 0,034 \\
\hline
\end{tabular}

These results indicate that the five indicators that reflect the individual farmer characteristics variable affect the improvement of the income level of layer hens farmers. It can be said that every single time there is an increase from the five indicators of the individual farmer characteristics variable $(\mathrm{X})$, it will cause an improvement in the income level of layer hens farmers in Bangli Regency, Bali Province. This can be understood because the increasing of age, level of formal education, knowledge, and length time as farmers will cause an increase in farmers maturity and more maturity of farmers in running their laying hens farms. Also, the increasing number of livestock ownership will automatically increase the income of the farmers themselves. Following the results of research from [19] reported that the variables that have a significant effect on beef cattle business income are the variables of beef cattle business costs, the number of livestock raised, and the cattle raising system. Meanwhile, the variable farming experience and length of farmers education did not have a significant effect. Meanwhile, [20] in their research inserted education in analyzing household and farming characteristics. The higher level of education will be made easier for family members to adopt technology so that they can rationally increase production to achieve maximum profits. [21] analyzed age, education, and training as variables affecting labor productivity in off-farm, farm work, and household work. The training, including outreach, aims to change the behavior of farmers for the better. The increasing productivity of farmers will also be accompanied by an increase in income. 


\section{Conclusion}

From the results of the direct effect test, it was proven that the individual farmer characteristics consisting of indicators of age $\left(\mathrm{X}_{1}\right)$, formal education $\left(\mathrm{X}_{2}\right)$, knowledge $\left(\mathrm{X}_{3}\right)$, number of livestock ownership $\left(\mathrm{X}_{4}\right)$, and length of farming $\left(\mathrm{X}_{5}\right)$ had a positive and significant impact on farmers income level, where knowledge $\left(\mathrm{X}_{3}\right)$ is the most dominant indicator influencing this variable. Every single time there is an increase in the five indicators of the Individual Farmers Characteristics variable (X), it will cause an increase in the income level of layer chicken farmers in Bangli Regency, Bali Province.

\section{Acknowledgement}

Our deep and sincere gratitude is given to God for giving us health and an opportunity to finish this writing. Thank you very much for our colleagues who have helped in the research and completed this writing. Special thanks to the chairman of Korpri Welfare Foundation of Bali Province, the Rector of Warmadewa University, the Dean of Agricultural Faculty of Warmadewa University, and also Head of Animal Husbandry Department of Warmadewa University.

\section{References}

[1] Z. Abidin, "Meningkatkan Produktivitas Ayam Ras Petelur," Jakarta: Agromedia Pustaka, 2003.

[2] Wiharto, "Manajemen Ternak Unggas," Malang: Universitas Brawijaya, 2002.

[3] I. K. Amrullah, "Nutrisi Ayam Petelur," Jakarta: Penebar Swadaya, 2004.

[4] Sudarmono. "Pedoman Pemeliharaan Ayam Ras Petelur," Yogyakarta: Kanasius, 2003.

[5] Badan Pusat Statistik Provinsi Bali, "Provinsi Bali Dalam Angka," Denpasar: BPS Provinsi Bali, 2019.

[6] P. S. Robbins, and T. A. Judge, "Perilaku Organisasi," Jakarta: Salemba Empat, 2012.

[7] I. G. A. M. P. Sanjaya, and N. Suparta. "Farmers Motivation to Raising Cow on Bali Cattle Breeding Business (Case Study at Pelaga Village, Petang District, Badung Regency)," 6th Int Conf on Sustainable Agriculture, Food and Energy IOP Conf. Series: Earth and Environmental Science, 2019.

[8] D. Hastuti, R. Subantoro, and M. Ismail, "Pengaruh Karakteristik Sosial Ekonomi Dan Jumlah Pakan Terhadap Pendapatan Peternak Sapi Perah Rakyat," Agronomika, vol. 12, no. 2, 2018.

[9] F. Rehman, S. Muhammad, I. Ashraf, K. Mahmood Ch., T. Ruby ,and I. Bibi, "Effect Of Farmers Socioeconomic Characteristics On Access Toagricultural Information: Empirical Evidence From Pakistan," J. of Animal \& Plant Sciences, vol. 23, no. 1, pp.324-329, 2013.

[10]M. Singarimbun, and S. Effendi, "Metode Penelitian Survai. Edisi Revisi," Jakarta: LP3ES, 1989. 
[11]I. Ghozali, "Structural Equation Modelling Metode Alternatif dengan Partial Least Square (PLS). Edisi 3," Semarang: Badan Penerbit Universitas Diponegoro, 2011.

[12]Z. Firmansyah, "Analisis Pengaruh Umur, Pendidikan, dan Upah Terhadap Produktivitas Kerja,” Economics Development Analysis Journal, vol. 4, no. 1, pp.9197, 2017.

[13] Soekartawi, "Prinsip Dasar Ekonomi Pertanian Teori dan Aplikasi," Jakarta: PT. Raja Grafindo, 2002.

[14]I. N. Suparta, "Pendekatan Holistik Membangun Agribisnis. Cetakan Pertama," Denpasar: Penerbit CV. Bali Media Adhikarsa, 2005.

[15] S. Azwar, "Sikap Manusia Teori dan Pengukurannya," Yogyakarta: Pustaka Pelajar, 2010.

[16] B. Riyanto, “Dasar-dasar Pembelanjaan Perusahaan,” Yogyakarta: BPFE, 2001.

[17]J. Makatita, "Tingkat Efektifitas Penggunaan Metode Penyuluhan Pengembangan Ternak Sapi Potong di Kabupaten Buru Provinsi Maluku," Agromedia. vol. 32, no. 2, 2014.

[18]M. Rivandi, and M. Jannah, "Pengaruh Biaya Pemeliharaan Dan Harga Jual Terhadap Pendapatan. (Studi Kasus Pada PT. Perindustrian Dan Perdagangan Lembah Karet," J. Sekolah Tinggi Ilmu Ekonomi KBP, pp.1-10, 2018.

[19]I. Indrayani, and Andri, "Faktor-faktor yang Mempengaruhi Pendapatan UsahaTernak Sapi Potong di Kecamatan Sitiung. Kabupaten Dharmasraya," J. Peternakan Indonesia, vol. 20, no. 3, pp.151-159, 2018.

[20] J. Chavas, R. Petrie, and M. Roth, "Farm household production efficiency: evidence from the Gambia," American Journal of Agricultural Economics, vol. 87, pp.160$179,2005$.

[21] B. W. Gould, and W. E. Saupe, “Off-Farm Labor Market Entry and Exit,” Am. J. Agric. Econ. Vol. 71, no. 4, pp.960-969, 1989. 